\title{
Sensory Ganglion
}

National Cancer Institute

\section{Source}

National Cancer Institute. Sensory Ganglion. NCI Thesaurus. Code C13060.

A cluster of nerve cell bodies that transmit sensory impulses and are located on either the dorsal root of a spinal nerve or on certain cranial nerves. 